\title{
The effect of an 8-month exercise program on bone density and some physical characteristics in sedentary women
}

\author{
Serkan HAZAR, Sedef KURT \\ School of Physical Education and Sport, Niğde University, Niğde, Turkey. \\ Address Correspondence to S. Hazar, shazar@nigde.edu.tr
}

\begin{abstract}
The aim of the study was to determine and evaluate the effect of an 8-month step-aerobic and run-walk exercise on bone density and some physical characteristics as weight, total fat mass, total fat percentile and lean mass at sedentary females 14 sedentary females with mean age 37.4 voluntarily participated in the study. Subjects performed an exercise program lasted an hour three days a week for eight months. Exercise program consisted of 45/50- minute step-aerobic one day a week; 30- minute run/walk and 30- minute stretching two days a week. Total bone mineral density (BMD), total bone mineral content (BMC), $\mathrm{T}$ score, $\mathrm{Z}$ score, Total lean mass, total fat mass and total fat percentile values were diagnosed by dual X-ray absorptiometry (DXA) (Norland XR-46). Wilcoxon signed rank test was used for data evaluation and significance level alpha was set at 0.05 . After the eight -month exercise program, it was found out that there was significant decrease in weight, BMI, and total fat mass $(\mathrm{p}<0.05)$. But the decreases in total fat percentile and lean mass were statically insignificant. Nevertheless the increasing in total BMD, T-score and Z-score were statically significant $(\mathrm{p}<0.05)$, while the decreases in total BMC value were statically insignificant. In conclusion the eight-month step-aerobic, run-walk and stretching exercises positively affected some anthropometric components as weight, BMI, and total fat mass. However the program didn't affect bone mineral contend in a positive way. But the program provides a preventive effect on bone density. It is suggested that preparation of exercise programs with similar purpose should include resistance exercise forms as well.
\end{abstract}

Keywords: Bone density; exercise; sedentary females.

\section{INTRODUCTION}

So many researchers indicated the positive effect of exercise on general health $(11,27)$. Moreover a lot of studies demonstrate exercise and physical activity positively effects bone mineral density (BMD) and body composition (32). Physical exercise can reduce clinical fracture incidence in postmenopausal women (24), though dedicated exercise protocols can positively affect fall risk (15), fall impact $(16,36)$, and bone strength (29). Sedentary life style and some other factors as immobility and some diseases, affect negatively both BMD and body composition such as weight and fat percentile.

Osteoporosis is a condition related to ageing, and acute episodes of pain associated with osteoporosis can lead to periods of restricted mobility and cardiopulmonary dysfunction in the elderly (6). Osteoporosis is a silent progressive systemic disease characterized by low bone mass and deterioration of bone tissue leading to bone fragility (10). Osteoporosis is a skeletal condition and is a primary cause for poor quality of life and increased medical expenses in those affected with this condition (2). The dramatic increase in osteoporosis over the last few decades may be explained by increasingly sedentary lifestyle. People who are less physically active during life are presumably to develop osteoporosis $(23,24,26)$

Physical activity throughout adulthood helps maintain bone density. Regular exercise decreases the rate of bone loses (21). Systemic physical activity also increases bone density and mass. The major factors for changes in the bone tissue are exercise intensity and load bearing. Increased bone density with high intensity exercise or increased load bearing is based on increases in calcium and hydroxyproline concentration in bones (35). It is difficult to determine precisely how much bone density is increased by physical activity; it is 
known, however, that these gains are lost when physical activity is discontinued (22).

Lots of study demonstrated that exercise increased BMD and decreased body mass index (BMI) and fat percentile especially postmenopausal women. But it wasn't well documented combined step-aerobic and run and walk exercise program on body composition and BMD in premenopausal sedentary women. We aimed of the study to determine and evaluate the effect of eight-mount step-aerobic and run and walk exercises on bone density and some physical characteristics as weight, total fat mass, total fat percentile and lean mass at sedentary premenopausal woman.

\section{METHODS \& METHOD}

\section{Subjects}

Initially 18 sedentary premenopausal women were included in the study, but 4 participants excluded from the study because of some personal reason. Totally 14 females with mean age 37.4 years voluntarily participated in the study. The study including criteria was healthy, non smokers, don't use any regular drugs and premenopausal women, Subjects performed an exercise program lasted an hour three days a week for eight months.

\section{Exercise program}

Exercise program consisted of 45/50- minute step aerobic one day a week; 30- minute run/walk and 30- minute stretching two days a week.

\section{Data Collections}

Total bone mineral density (BMD), total bone mineral content (BMC), $\mathrm{T}$ score, $\mathrm{Z}$ score, Total lean mass, total fat mass and total fat percentile values were diagnosed by dual X-ray absorbtiometry (DXA) Norland XR-46. The whole body DXA exams were acquired according to the procedures recommended by the manufacturer. All subjects changed into paper gowns and were asked to remove all jewelry and other personal effects that could interfere with the DXA result.

\section{Statistical Analyses}

The collecting data were evaluated SPSS program. Wilcoxon signed rank test was used for the comparison before and after exercise program values. Significance level alpha was set at 0.05.

\section{RESULTS}

After the exercise program, it was found out that there was significant decrease in weight $(p<0.01)$. BMI and total fat mass $(p<0.05)$ but the decreases in total fat percentile and total lean mass were not statically significant. Nevertheless, the increases in total $\mathrm{BMD}, \mathrm{T}$-score and Z-score were statically significant $(p<0.05)$, while the decreases in total BMC value were statically insignificant.

\section{DISCUSSION}

Aging period is prominent by the decreasing physiological and functional capabilities. This decline in function result the loss of muscular strength and related impaired functional mobility (7) and the loss of muscle strength and capability with aging leads to muscular dysfunction (3). Sedentary life style or lack of physical activity is one of the leading causes of preventable death worldwide (28). A sedentary lifestyle and lack of physical activity can contribute to risk factor. Fatness and osteoporosis is some of these factors.

Table 1. Comparison of anthropometric values before and after the exercise program.

\begin{tabular}{llccc}
\hline Variables & & Mean \pm SD & Z value & $\mathrm{p}$ \\
\hline \multirow{2}{*}{ Weight $(\mathrm{kg})$} & Before Exercise Program & $70.85 \pm 11.50$ & -2.637 & $0.008^{* *}$ \\
& After Exercise Program & $67.78 \pm 11.82$ & & \\
BMI & Before Exercise Program & $27.27 \pm 3.88$ & -2.341 & $0.019^{*}$ \\
& After Exercise Program & $26.08 \pm 4.61$ & & \\
Total Fat (\%) & Before Exercise Program & $33.64 \pm 4.14$ & -1.265 & 0.206 \\
& After Exercise Program & $32.10 \pm 4.21$ & & \\
Total Fat Mass (gr) & Before Exercise Program & $24470.92 \pm 6578.62$ & -2.01 & $0.047^{*}$ \\
& After Exercise Program & $23020.42 \pm 6562.69$ & & \\
Total Lean Mass (gr) & Before Exercise Program & $44824.00 \pm 6264.73$ & -1.287 & 0.198 \\
& After Exercise Program & $44332.42 \pm 5715.59$ & & \\
\hline
\end{tabular}


Table 2. Comparison of Bone Mineral values before and after the exercise program

\begin{tabular}{|c|c|c|c|c|}
\hline Variables & & Mean \pm SD & $Z$ value & $\mathrm{p}$ \\
\hline \multirow[t]{2}{*}{ Total BMD (g/cm2) } & Before Exercise Program & $1.04 \pm 0.085$ & -2.281 & $0.023^{*}$ \\
\hline & After Exercise Program & $1.07 \pm 0.086$ & & \\
\hline \multirow[t]{2}{*}{ Total BMC (gr) } & Before Exercise Program & $2688.64 \pm 270.07$ & -0.220 & 0.826 \\
\hline & After Exercise Program & $2690.64 \pm 279.30$ & & \\
\hline \multirow[t]{2}{*}{ T score } & Before Exercise Program & $0.37 \pm 0.85$ & -2.198 & $0.028^{*}$ \\
\hline & After Exercise Program & $0.59 \pm 0.08$ & & \\
\hline \multirow[t]{2}{*}{ Z score } & Before Exercise Program & $1.18 \pm .98$ & -2.292 & $0.022^{*}$ \\
\hline & After Exercise Program & $1.41 \pm .94$ & & \\
\hline
\end{tabular}

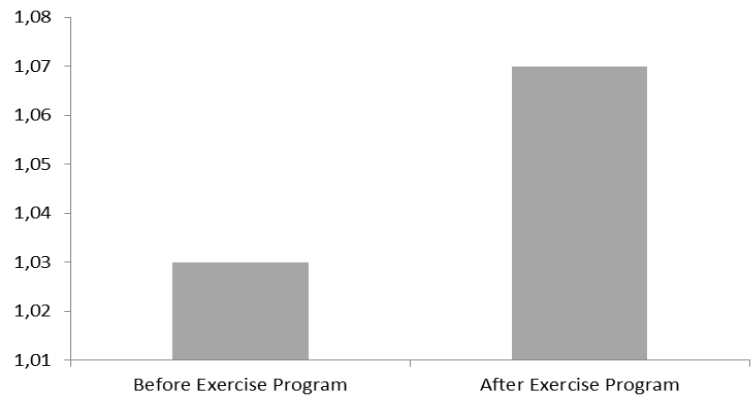

Figure 1. Total BMD $\left(\mathrm{g} / \mathrm{cm}^{2}\right)$.

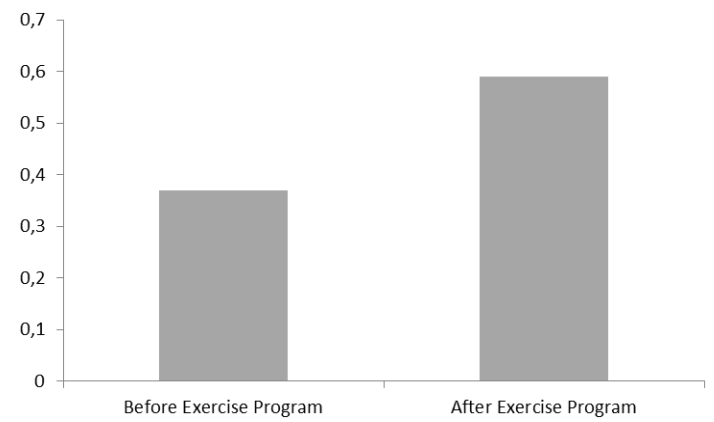

Figure 3. T score.

Exercise has been recommended strongly by researchers for prevention of such disorders (14) and exercise can result in optimal improvement in body composition (19). In the literature different type of exercises recommended that different purpose. For instance aerobic exercise the more effective than resistance exercise on cardiopulmonary disorder (12). Conversely resistance exercises advised for bone and muscle fitness $(4,10,18)$. In the study was applied combined with step-aerobic, stretching and runwalk exercise and examined it effect on body composition and bone structures.

Body fat percentile, BMI, weight and total fat mass provides important information about body composition and fatness. At the sometime total $\mathrm{BMD}$, total BMC $\mathrm{T}$-score and $\mathrm{Z}$ - sore provide

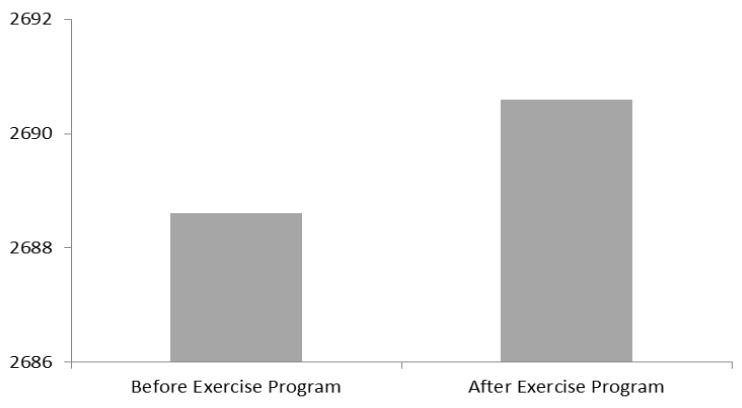

Figure 2. Total BMC (gr).

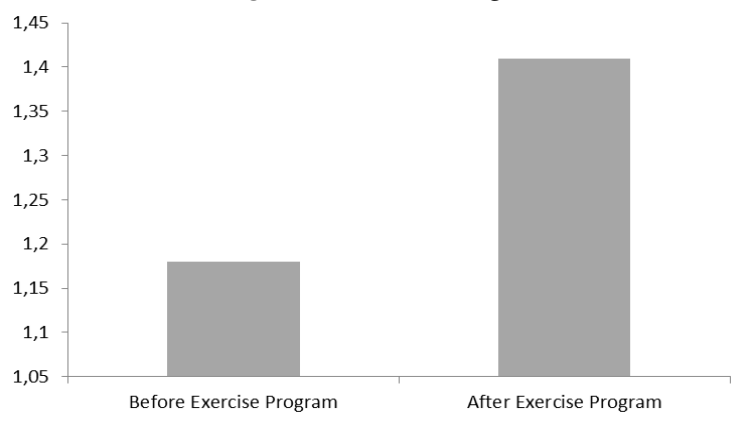

Figure 4. $\mathrm{Z}$ score.

information about bone structure. Thus we determined these variables in this study.

Researchers used a manufacturer-supplied reference dataset of healthy young adult female BMD values and identified a Z-score (a score expressed in standard deviation units from a given mean of age-matched controls) $<-2.0$ as an equivalent of osteoporosis (13).

In this study the firs remarkable findings are significantly decrease $(\mathrm{p}<0.05)$ of weight and BMI after the combined exercise program. However total fat percentile changes were insignificant the decreases of the total fat mass was statically significant after the program. The decrease of total lean mass wasn't remarkable. In the study provided that combined exercise program positively affected some body component. There 
have a lots of study indicated that favorable effect of exercise on body fat mass, weight and BMI $(1,17,25)$.

After the combined exercise program total BMC values changes wasn't significant. But the increases of the total BMD, $\mathrm{T}$ score and $\mathrm{Z}$ score after the exercise was statically significant. Deng (10) reported that the 12 months combined with strengthening, aerobics and yoga exercise program reduced the rate of bone loss. Movaseghi \& Sadeghi (30) reported that moderate multicomponent exercise training positively effect on bone mineral density and bone mineral content in a female subject with osteoporosis. And they underline positive effects; regular and lifelong exercise training must be incorporated into peoples' life due to the chronic nature of bone loss in aging process. Another study reported that the above 12-week program improved fitness and bone density in HIV-infected treated subjects (5). Nambi (31) suggested that strength training program helps to increase bone mineral density in post-menopausal women with type 1 osteoporosis. Tartibian \& Saei (34) suggested that adequate weight-bearing exercise was essential to build peek bone mass and reduce the risk of later fracture. Most previous intervention studies have suggested that regular exercise or physical activity might increase bone mass $(8,20,23,24)$. Strain as a stimulus bone adaptation. Forces from muscle contraction and impact loading provoke compression, tension and torsion. The primary stimulus for bone activation is strain magnitude and degree of distortion. Activity such as gymnastic, bearing weight, rapid acceleration and involve strong muscle contraction most effectively bone mass (35).

Pre-menopausal osteoporosis is not uncommon. But the protection and enhancement of bone mineral density and content of premenopausal stage is important in terms of the healthier postmenopausal stage. Thus, when preparing an exercise program for women must be take into account bone health.

In conclusion the eight-month step-aerobic, run-walk and stretching exercises positively affected some anthropometric components as weight, BMI, and total fat mass. However the program didn't affect bone mineral contend in a positive way. But the program provides a preventive effect on bone density. It is suggested that preparation of exercise programs with similar purpose should include resistance exercise forms as well.

\section{REFERENCES}

1. Al-Zadjali M, Keller C, Larkey LK, Albertini L. Writing Group: The Center for Health Outcomes in Aging Evaluation of Intervention Research in Weight Reduction in Post-Menopausal Women. Geriatr Nurs, 2010; 31(6); 419434.

2. Atik OS. Gunal I. Korkusuz F Burden of osteoporosis. Clin Orthop Relat Res. Feb 2006; 443: 19-24.

3. Baumgartner RN. Koehler KM. Gallagher D. et al.: Epidemiology of sarcopenia among the elderly in New Mexico. Am J Epidemiol, 1998; 147:755-763

4. Blalock SJ, DeVellis RF, Giorgino KB, DeVellis BM, Gold DT. Osteoporosis Prevention in Premenopausal Women: Using a Stage Model Approach to Examine the Predictors of Behavior Health Psychol, 1996; 15(2): 84-93.

5. Bonato M, Bossolasco S, Galli L, Pavei G, Testa M, Bertocchi C, Galvano E, Balconi G, Lazzarin A, Merati G, La Torre A, Cinque $P$. Moderate aerobic exercise (brisk walking) increases bone density in CART-treated persons. Journal Of The International AIDS Society, 2012; 6(Suppl 4): 1.

6. Carter MI, Hinton PS Physical activity and bone health. Mo Med. 2014. 111(1): 59-64

7. Cavani V, Mier C, Muston AA, Musto AA, Tummers N. Effects of a 6-week resistance training program on functional fitness of older adults. J Aging Phys Act, 2002. 10:443-452.

8. Clifford J. Postmenopausal osteoporosis. N Engl J Med, 2005; 353(6): 595-603.

9. Cullen DM, Iwaniec UT, Barger-Lux MJ. Skeletal Responses to Ezercise and Training. In Exercise and sport science. Ed. Garrett WE, Kirkendall DT. Philadelphia: Lippincott Williams \& Wilkins, 67-95. 2000

10. Deng S. Effects of exercise therapy on bone mineral density in early postmenopausal women: a controlled trial Frontiers of Medicine in China, 2009; 3(3): 323-329.

11. Deslandes A. Moraes H. Ferreira C. Veiga H. Silveira H. Mouta R Pompeu FA, Coutinho ES, Laks J. Exercise and mental health: many reasons to move. Neuropsychobiology, 2009; 59: 191-8.

12. Dougherty CM, Glenny R, Kudenchuk PJ. Aerobic exercise improves fitness and heart rate variability after an implantable cardioverter defibrillator. J Cardiopulm Rehabil Prev, 2008; 28(5): 307-11.

13. Galusca B. Zouch M, Germain N, Bossu C, Frere D. Lang F, Lafage-Proust $\mathrm{MH}$, Thomas T, Vico L, Estour B. Constitutional thinness: unusual human phenotype of low bone quality. J Clin Endocrinol Metab, 2008; 93(1): 110-7.

14. Fletcher GF, Balady G, Blair SN, Blumenthal J, Caspersen C, Chaitman B, Epstein S, Sivarajan Froelicher ES, Froelicher VF, Pina IL, Pollock ML. Statement on Exercise: Benefits and Recommendations for Physical Activity Programs for All Americans. A Statement for Health Professionals by the Committee on Exercise and Cardiac Rehabilitation of the Council on Clinical Cardiology. American Heart Association PED; Circulation, 1996; 94: 857-862. 
15. Gillespie LD, Robertson MC, Gillespie WJ, Sherrington C, Gates S, Clemson LM, Lamb SE. Interventions for preventing falls in older people living in the community. Cochrane Database Syst Rev, 2012; 12;9: CD007146.

16. Groen BE, Smulders E, de Kam D, Duysens J, Weerdesteyn V. Martial arts fall training to prevent hip fractures in the elderly. Osteoporos Int, 2010; 21:215-221.

17. Herman KM, Sabiston CM, Tremblay A, Paradis G. Selfrated health in children at risk for obesity: associations of physical activity. Sedentary Behaviors and BMI. Journal of Physical Activity \& Health, 2014; 11(3). 543-552. doi:10.1123/jpah.2012-0124

18. Iki M, Saito Y, Dohi Y, Kajita E, Nishino H, Yonemasu K, Kusaka Y. Greater trunk muscle torque reduces postmenopausal bone loss at the spine independently of age, body size, and vitamin $\mathrm{D}$ receptor genotype in Japanese women. Calcif Tissue Int, 2002; 71(4): 300-307.

19. Irandoust $K$, Taheri $M$. The effects of aquatic exercise on body composition and nonspecific low back pain in elderly males. Journal of Physical Therapy Science, 2015; 27(2): 433 435

20. Kelley GA, Kelly KS, Tran ZV. Exercise and lumbar spine bone mineral density in postmenopausal women: a metaanalysis of individual patient data. J Gerontol A Biol Sci Med Sci, 2002; 57(9): 599-64.

21. Kemmler W, Engelkek K, Lauber D, Weineck J, Hensen J, Kalender WA. Exercise effects on fitness and bone mineral density in early postmenopausal women: 1-year EFOPS results. Med Sci Sports Exerc, 2002; 34(12): 2115-2123.

22. Kemmler W, von Stengel S. Dose-response effect of exercise frequency on bone mineral density in post-menopausal. osteopenic women. Scand J Med Sci Sports, 2014; 24:526-34

23. Kemmler W, von Stengel S. Exercise frequency, health risk factors, and diseases of the elderly. Arch Phys Med Rehabil, 2013; 94: 2046-53.

24. Kemmler W, Bebenek M, Kohl M, Von Stengel S. Exercise and fractures in postmenopausal women. Final results of the controlled Erlangen Fitness and Osteoporosis Prevention Study (EFOPS). Osteoporos Int, Epub 2015 May 12

25. Kerksick CM, Wismann-Bunn J. Fogt D. Thomas AR. Taylor L. Campbell BI, Wilborn CD, Harvey T, Roberts MD, La Bounty P, Galbreath M, Marcello B, Rasmussen CJ, Kreider RB. Changes in weight loss, body composition and cardiovascular disease risk after altering macronutrient distributions during a regular exercise program in obese women. Nutr J, 2010; 22: 9(1):59

26. Korpelainen R, Korpelainen J, Heikkinen J, Väänänen K, Keinänen-Kiukaanniemi S. Lifelong factor for osteoporosis and fractures in elderly women with low body mass index. Bone. 2003. 39: 385-391.

27. Lauren C, Nishimura K, Margaret L, Lau H, Culos-Reed S. The impact of physical activity on health-related fitness and quality of life for patients with head and neck cancer: A systematic review. Heart, 2015; doi:10.1136/bjsports-2015094684.

28. Lopez AD, Mathers CD, Ezzati M, Jamison DT, Murray CJ. Global and regional burden of disease and risk factors. 2001: systematic analysis of population health data. Lancet, 2006; 367(9524): 1747-57.

29. Marques EA, Mota J, Carvalho J. Exercise effects on bone mineral density in older adults: a meta-analysis of randomized controlled trials. Age, 2011; 34:1493-515.

30. Movaseghi F, Sadeghi H. Effect of three-year multicomponent exercise training on bone mineral density and content in a postmenopausal woman with osteoporosis: a case report. Iranian Journal of Public Health, 2015; 44(5). 701-704.

31. Nambi G, Momin S, Nagar R, Patel S, Pancholi D. Parth Trivedi Comparative effect of strength training program and aerobic training program on bone mineral density in post menopausal women with type-1 osteoporosis. Journal of pharmaceutical biology, 2014; 4(2): 61-65.

32. Nikander R, Sievanen H, Heinonen A, Daly RM, Uusi-Rasi K, Kannus P. Targeted exercise against osteoporosis: a systematic review and meta-analysis for optimising bone strength throughout life. BMC Med, 2010; 8:47.

33. Rackoff PJ, Barnes K J, Honig S. Exercise and Its Effect on Bone Health. The Open Arthritis Journal, 2009; 2: 14-17.

34. Tartibian B, Saei NM. Effects of 9-weeks high intensity aerobic exercises on hormones and marker of metabolism of bone formation in young women. Research Journal of Biological Sciences, 2008; 3(5): 519-524.

35. Viru A, Viru M. Nature of training effects. In Exercise and sport science. Ed. Garrett WE, Kirkendall DT. Philadelphia: Lippincott Williams \& Wilkins 67-95. 2000.

36. Weerdesteyn V, Groen BE, van Swigchem R, Duysens J. Martial arts fall techniques reduce hip impact forces in naive subjects after a brief period of training. J Electromyogr Kinesiol, 2008; 18: 235-42. 